
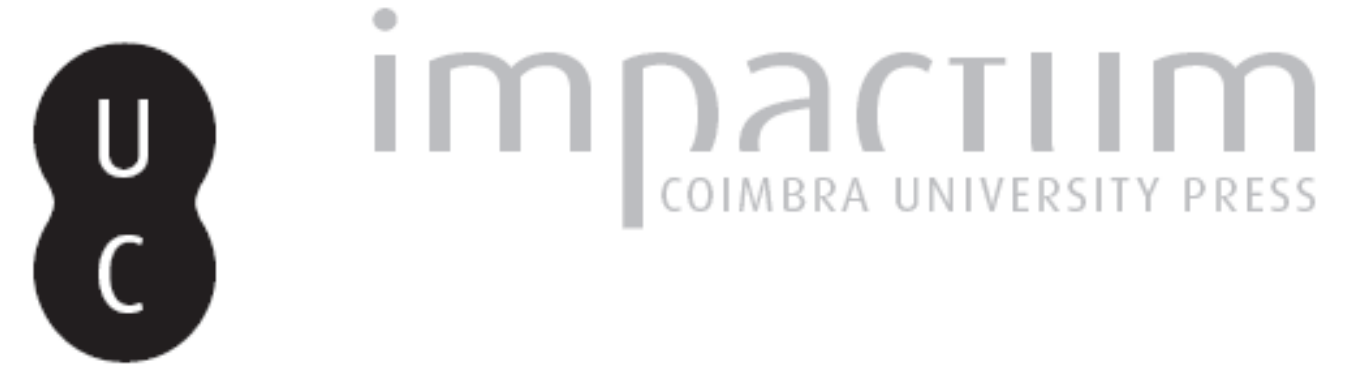

No dia em que a morte chegar (decifrando o regime jurídico das diretivas antecipadas de vontade)

\author{
Autor(es): $\quad$ Raposo, Vera Lúcia
}

Publicado por: Imprensa da Universidade de Coimbra

URL persistente:

URI:http://hdl.handle.net/10316.2/33226

DOI:

DOI:http://dx.doi.org/10.14195/1647-8630_24_6

Accessed : $\quad$ 26-Apr-2023 14:24:37

A navegação consulta e descarregamento dos títulos inseridos nas Bibliotecas Digitais UC Digitalis, UC Pombalina e UC Impactum, pressupõem a aceitação plena e sem reservas dos Termos e Condições de Uso destas Bibliotecas Digitais, disponíveis em https://digitalis.uc.pt/pt-pt/termos.

Conforme exposto nos referidos Termos e Condições de Uso, o descarregamento de títulos de acesso restrito requer uma licença válida de autorização devendo o utilizador aceder ao(s) documento(s) a partir de um endereço de IP da instituição detentora da supramencionada licença.

Ao utilizador é apenas permitido o descarregamento para uso pessoal, pelo que o emprego do(s) título(s) descarregado(s) para outro fim, designadamente comercial, carece de autorização do respetivo autor ou editor da obra.

Na medida em que todas as obras da UC Digitalis se encontram protegidas pelo Código do Direito de Autor e Direitos Conexos e demais legislação aplicável, toda a cópia, parcial ou total, deste documento, nos casos em que é legalmente admitida, deverá conter ou fazer-se acompanhar por este aviso.

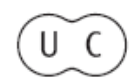


RE VISTA P O R T U G U E S A
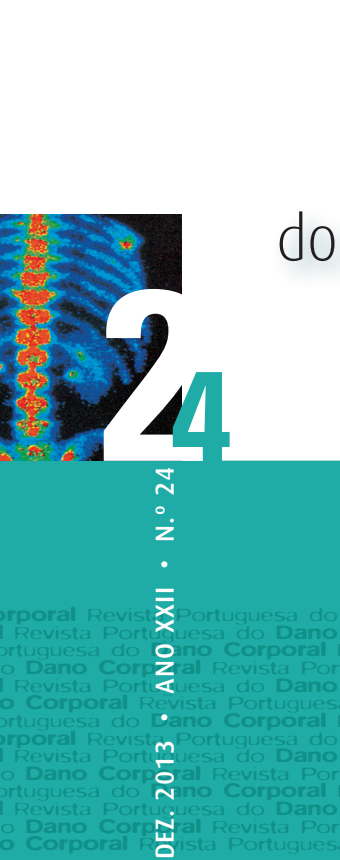

$$
\text { RE VISTA P OR TU/G U E S A }
$$

do

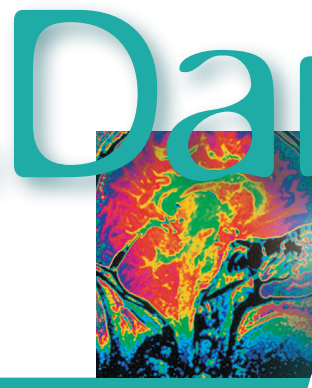

ন

$\stackrel{\circ}{\dot{z}}$

$\dot{\bar{x}}$

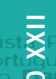

Ono Corporal Revistaral Revista Portuming

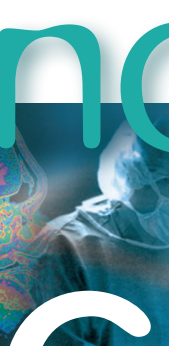

(9)

12

tै. strentes

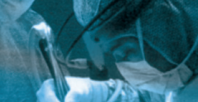

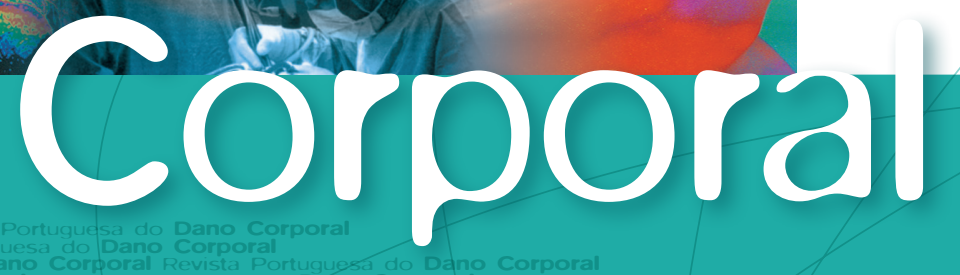

-

m Portuguesa do Dano Corporal Revista Portuguesa do Qano Corporal

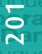
ristal

Corporal Revista Portuquesa do Dano Corpograi Revista Portuquesa do Dang Corporal

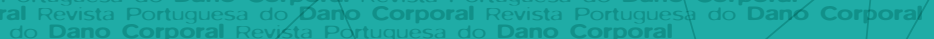

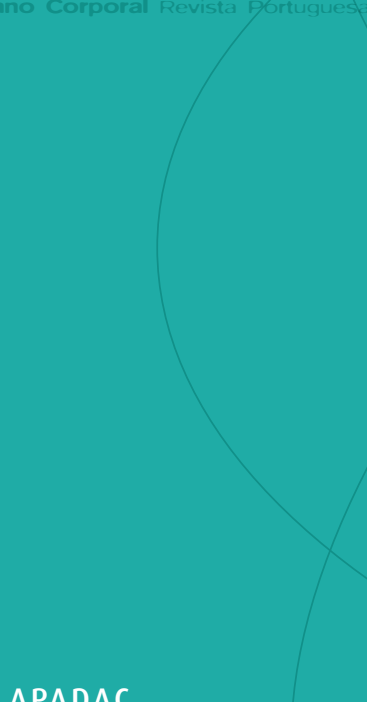

APADAC

ASSOCIAÇÃO PORTUGUESA

DE AVALIAÇÃO

DO DANO CORPORAL

FACULDADE DE MEDICINA

DA UNIVERSIDADE

DE COIMBRA 


\section{No dia em que a morte chegar (decifrando o regime jurídico das diretivas antecipadas de vontade)}

Vera Lúcia Raposo ${ }^{1}$

Ao lado daquela que foi desde sempre a obrigação tradicional dos prestadores de cuidados de saúde - fornecer ao paciente os cuidados médicos mais adequados ao seu caso - consolidou-se nos últimos anos uma outra obrigação paralela (mas não por isso secundária), qual seja, a de informar o paciente acerca do seu estado de saúde ${ }^{2}$ e, consequentemente, respeitar a vontade por este expressa ou, pelo menos, aquela que se deduz ser a sua ${ }^{3}$.

Esta nova obrigação médica assumiu tal importância que inclusivamente (re)conformou aquela primeira. Assim, se tradicionalmente os melhores cuidados médicos traduziam aqueles que permitiam manter a vida do paciente, sem cuidar particularmente das concretas condições dessa vida, hoje em dia trata-se sobretudo de lhe garantir uma vida com qualidade ${ }^{4}$. Nesta medida, tem-se defendido que em certas situações extremas as leges artis ditam a omissão/interrupção do tratamento médico ${ }^{5}$, sobretudo - e será deste ponto que iremos cuidar no presente estudo - quando essa seja a vontade do paciente.

1 Professora Auxiliar da Faculdade de Direito da Universidade de Coimbra

Centro de Direito Biomédico e Centro de Direitos Humanos

Associada Consultora da Vieira de Almeida e Associados

2 Sobre o consentimento informado em termos gerais, Manuel da Costa ANDRADE, "Art. 156.", p. 595/631 e "Art. 157.”", p. 632/640; ERS, Consentimento Informado...; Jean-Luc FAGNART, "Information du Patient...", p. 51/97 ; Julio César GALÁN CORTÉS, "La Responsabilidad Médica..."; Giulia SANDOR, "Obbligo di Informazione Medica...", 529/550; Markus PARZELLER, et al. „Patient Information...”, p. 576/586; André Dias PEREIRA, O Consentimento Informado... e "Novos Desafios..."; Vera Lúcia RAPOSO, "Directivas Antecipadas de Vontade...", p. 196 ss., "Entre a Vida e a Morte...", p. 115 ss. e Do Ato Médico, p. 169 ss e 216 ss.

3 Sobre consentimento presumido, Manuel da Costa ANDRADE, "Consentimento em Direito Penal Médico...", p. 117/148 e, do mesmo autor, “Art. 156.””, p. 615/628.

4 Sobre a questão da qualidade de vida versus quantidade de vida, Vera Lúcia RAPOSO, "Directivas Antecipadas de Vontade...", p. 184 ss. e "Entre a Vida e a Morte...", p. 123 ss.

5 Vera Lúcia RAPOSO, "Directivas Antecipadas de Vontade...", p. 184 ss. e "Entre a Vida e a Morte...", p. 122 ss. 


\section{As Diretivas Antecipadas de Vontade}

\subsection{0 consentimento do paciente}

\subsubsection{A recusa de cuidados de saúde}

Depois se ter firmado a tese de que o consentimento do paciente é um prius essencial de qualquer ato médico - configurando inclusivamente uma autónoma lex artis $^{6}$ - surgiu a questão de saber como e quando deve esse consentimento ser prestado. A dúvida coloca-se porque é sabido que muitas vezes o paciente não está em condições de manifestar qualquer vontade. Logo, questiona-se como deve o médico atuar perante um paciente inconsciente, especialmente quando a urgência do ato não se compadeça com delongas ${ }^{7}$.

Uma hipótese pensável - defendida entre nós durante muito tempo e ainda hoje sustentada por doutrina minoritária ${ }^{8}$ - seria entender que o médico deve sempre atuar para melhorar o estado de saúde do paciente ou, pelo menos, quando se trate de lhe salvar a vida. Porém, esta posição doutrinal não conta com apoio na mais moderna doutrina do direito médico e dos direitos humanos, nem tão-pouco colhe qualquer respaldo na lei portuguesa9 .

De facto, e ao contrário do que sustentam alguns autores, a norma do Código Penal (CP) que exige o consentimento (informado, segundo o artigo 157..$^{\circ}$ do $\mathrm{CP}$ ) do paciente - o artigo $156 .^{\circ}$ do $\mathrm{CP}$ - não inclui qualquer ressalva quando à possibilidade de exclusão deste requisito. Nem mesmo uma leitura conjunta desta norma com a do artigo $154 . \% / 3 / b$ do $\mathrm{CP}^{10}$ permitiria chegar a

Quanto à diferença (ou ausência dela) entre omissão e interrupção de tratamento, ver Vera Lúcia RAPOSO, e "Entre a Vida e a Morte...", p. 135/137.

6 Vera Lúcia RAPOSO, Do Ato Médico..., p. 214.

7 Por conseguinte, a atendendo à natureza própria das circunstâncias em que trabalham, pode questionar-se se as equipas de emergência médica do INEM estão vinculadas à eventual DAV de que o paciente seja portador.

8 Teresa Quintela de BRITO, "Responsabilidade Penal dos Médicos...”, p. 403 ss., 408 ss. e "Interrupção de Alimentação...", p. 584. Ainda Teresa Quintela de BRITO, et al., "Crimes Contra a Vida...", p. 58 ss.

9 Vera Lúcia RAPOSO, "Directivas Antecipadas de Vontade...", p. 198/204 e "Entre a Vida e a Morte...”, p. 125 ss.

10 Artigo 154.\%1 CP - "Quem, por meio de violência ou de ameaça com mal importante, constranger outra pessoa a uma acção ou omissão, ou a suportar uma actividade, é punido com pena de prisão até três anos ou com pena de multa".

Artigo 154. $\% / 3 / \mathrm{b} \mathrm{CP}$ - O facto não é punível:

b) Se visar evitar suicídio ou a prática de facto ilícito típico. 
tal conclusão, uma vez que este segundo preceito apenas permite afastar a ilicitude da conduta do médico que atue, inclusivamente recorrendo à força, para salvar a vida de um suicida. Porém, daqui não decorre que o médico tenha a obrigação de o fazer, simplesmente, não praticará um crime aquele que o faça. De modo que tão lícita será a conduta do médico que atua como a daquele que não atua. Mas, e mais importante ainda, este preceito vale apenas para suicidas, os quais devem estar previamente diagnosticados como tal, o que obviamente não inclui pacientes que recusam um ato médico. A recusa de tratamento não pode ser considerada suicídio, nem mesmo quando daí advenha a sua morte, pois trata-se apenas de uma afirmação do direito fundamental à autodeterminação sobre matérias relativas ao corpo, à saúde e à vida, o qual resulta do direito ao desenvolvimento da personalidade do artigo $26 . \%$ da CRP.

Porém, esta ênfase na vontade do paciente defronta-se com um obstáculo de monta: a incapacidade temporária (porque se for permanente existirá, ou será nomeado, um representante do incapaz) de pacientes inconscientes.

Uma vez que o consentimento presumido (que adiante se explicitará) se revelava problemático, sobretudo face a pacientes com os quais o médico não tivera qualquer contacto prévio, começou a desenhar-se a ideia de que o paciente poderia manifestar a priori a sua vontade. Assim surgiram as Diretivas Antecipadas de Vontade (DAV's).

\subsubsection{As DAV's e as práticas eutanásicas}

Embora usualmente conexionadas com as práticas eutanásicas, note-se que as DAV's não se confundem com atos deliberadamente praticados com o intuito de provocar a morte da pessoa, a chamada eutanásia ativa direta ${ }^{11}$.

Porém, é certo que as DAV's mantêm afinidades com a eutanásia passiva, uma vez que se trata afinal de não aplicar um determinado tratamento e deixar assim a natureza e a morte seguir o seu curso natural. Mas a verdade é que a eutanásia passiva é desde há muito aceite com algum consenso pela deontologia médica, pela prática jurídica e mesmo por alguns sectores da religião católica. É que não se trata de introduzir aqui uma nova causa de morte, mas apenas de deixar seguir uma causa previamente existente, a qual em nada se deve ao médico ou a decisões do paciente, mas sim à doença com que este último se confronta. Como já deixámos escrito, “[a]s DAV's surgem precisamente para fazer face às situações em que o paciente já entrou

11 Sobre a distinção entre as várias formas de eutanásia, Susana Sanz CABALLERO, "El Comienzo y el Fin de la Vida...", p. 168 ss.; Maria Elisa VILLAS-BÔAS, "A Ortotanásia...", p. 62 ss.; Vera Lúcia RAPOSO, "Self-Determination in the End of Life...", "Directivas Antecipadas de Vontade...", p. 184/192 e ainda "Entre a Vida e a Morte...", p. 122 ss. 
em processo de morte (ou seja, esta surge como um resultado inevitável a muito curto prazo), de tal forma que o médico nada pode fazer para a evitar (e inclusivamente qualquer medida que tome se arrisca a aumentar o grau de dor e incómodo), restando-lhe apenas providenciar ao paciente maior conforto e tranquilidade, diminuindo-lhe o sofrimento"12.

\subsubsection{A atualidade da vontade do paciente}

O momento temporal da manifestação do consentimento tem sido um dos principais óbices à admissibilidade legal das DAV's como documentos vinculativos. É que a regra da atualidade do consentimento parece opor-se a vontades manifestadas antes da necessidade do ato médico sequer surgir, muitas vezes mesmo com vários anos de antecedência, o que se arrisca a tornar o consentimento menos atual, logo, inválido.

Para acautelar o perigo de desatualização da vontade do paciente - exatamente o risco que se pretende evitar mediante a exigência de consentimentos atuais - o legislador optou por fixar um prazo de validade à DAV de cinco anos a partir do momento da sua assinatura, findo o qual deve a mesma ser renovada para se manter em vigor, sempre por igual período, não existindo limite ao número de renovações admitidas (n. ${ }^{\circ} \mathrm{s} 1$ e 2 do artigo $7 .^{\circ}$ da Lei n. ${ }^{\circ}$ 25/2012).

Para além do mais - e como não poderia deixar de ser - o artigo $8 .^{\circ}$ prevê a possibilidade de as DAV's serem modificadas ou revogadas a qualquer momento, desde que obedecendo aos mesmos formalismos e requisitos cominados no artigo 3..$^{\circ}$ para a celebração da DAV. Porém, estes requisitos parecem apenas valer caso a alteração ocorra fora do âmbito de uma prestação de cuidados de saúde. Pois a norma do artigo 8.\%/4 da Lei n. ${ }^{\circ}$ 25/2012 estipula que o titular da DAV pode, a qualquer momento e mediante mera declaração ao responsável pela assistência médica que lhe está a ser prestada, alterar ou revogar a sua DAV. Nem poderia deixar de se admitir esta possibilidade, sob pena de vincular o paciente a uma vontade que manifestou a certa altura mas que hoje, já hospitalizado, não pretende manter. Ou seja, o seu direito ao arrependimento e a mudar de opinião é salvaguardado até ao último momento possível. O único formalismo exigido é que a dita alteração/revogação seja incluído no processo clínico do paciente, comunicada ao Registo Nacional do Testamento Vital (o RENTEV é o órgão a criar para efeitos de registo das DAVS's) quando se trate de uma DAV aí registada e transmitida igualmente ao PCS quando exista (o que demonstra que o legislador aceita inequivocamente o uso simultâneo das duas modalidades de DAV's).

12 Vera Lúcia RAPOSO, “Entre a Vida e a Morte...”, p. 119. 


\subsection{Modalidades de DAV's}

As DAV's podem assumir duas modalidades, uma que se aproxima do tradicional testamento patrimonial para disposição de bens após a morte, denominado de testamento vital; outra com refrações à figura do representante legal, a que a lei chama de Procurador de Cuidados de Saúde (PCS) ${ }^{13}$.

O testamento vital é semelhante ao testamento usado para dispor dos bens após a morte, tratando-se agora de dispor sobre os atos médicos que a pessoa de antemão aceita ou recusa, para que tal vontade possa valer quando não esteja em condições de a manifestar.

Contudo, aponta-se ao testamento vital o facto de raciocinar no abstrato, pois que a antecipação da decisão face ao momento da sua efetiva eficácia não lhe permite ter em consideração especificidades da situação concreta que poderiam ditar solução diferente se consideradas.

A esta luz, a figura do PCS - uma espécie de representante legal com poderes delimitados à decisão relativa à prestação de cuidados de saúde (artigo 12. ${ }^{\circ}$ da Lei n. ${ }^{\circ}$ 25/2012, cujo n. ${ }^{\circ} 2$ remete para as normas do Código Civil, CC, que regulam o instituto de procuração) - apresenta-se como uma mais-valia, dado que a decisão pode ser tomada no preciso momento em que a questão se suscita, por conseguinte, atendendo a eventuais desenvolvimentos da ciência que poderiam não ser tidos em conta na redação do testamento vital; ou àquele prognóstico particularmente favorável que o paciente apresenta atendendo ao seu estado clínico e que constitui exceção à situação comum dos pacientes

13 No artigo $1 .^{\circ}$ da Lei n..$^{\circ}$ 25/2012 o legislador esclarece que a presente regulação "estabelece o regime jurídico das diretivas antecipadas de vontade (DAV) em matéria de cuidados de saúde, designadamente sob a forma de testamento vital (TV), regula a nomeação de procurador de cuidados de saúde", o que dá a entender que o testamento vital e o PCS são duas modalidades de DAV's, como aliás se tem sustentado desde sempre. Esta mesma ideia é corroborada pelo $\mathrm{n} .{ }^{\circ} 1$ do artigo $2 .^{\circ}$, que começa por dizer que "[a]s diretivas antecipadas de vontade, designadamente sob a forma de testamento vital", sugerindo assim que o PCS seria a outra forma de DAV.

Porém, depois de um capítulo II dedicado às DAV's insere um capítulo III exclusivamente referente ao PCS, sem um concomitante capítulo específico do testamento vital, como se o capítulo II apenas a este se referisse, o que, porém, parece não ser certo atendendo ao já referido teor do artigo 2.\%1. Por outro lado, no artigo $15 .^{\circ}$, quando se refere ao RENTEV, declara que este trata de questões relativas ao "documento de diretivas antecipadas de vontade e à procuração de cuidados de saúde", como se estas segundas não fossem uma modalidade de DAV's. Mais estranho ainda é que a entidade competente para "gerir" as DAV's tome a designação de Registo Nacional de Testamento Vital (RENTEV), como se apenas deste tratasse, quando é o próprio artigo $15 .^{\circ}$ que igualmente lhe atribui competências em matérias de procurações aos PCS's. Não obstante estas incongruências do texto legal, cremos que sempre que o legislador se refere às DAV's pretende abarcar as suas duas modalidades - testamento vital e PCS (e respetiva procuração) - exceto quando, atendendo às especificidades próprias de cada um, a norma em causa não lhe seja aplicável. 
que apresentam aquele mesmo estado clínico, pelo que dificilmente seria esta especificidade tida em conta num eventual documento previamente redigido.

Todavia, o PCS também apresenta alguns inconvenientes, dado que a decisão acaba por ser tomada por alguém que não o próprio paciente, sem garantia de que esta decisão coincide com a decisão que aquele haveria tomado se estivesse capaz de o fazer. Para obviar a discrepâncias graves entre as duas vontades algumas cautelas devem ser tomadas, sendo que nem todas foram tidas em consideração pelo nosso legislador. Antes de mais, o PCS deve ser escolhido pelo próprio paciente (artigo 11.\%/1 da Lei n. ${ }^{\circ}$ 25/2012) ${ }^{14}$. Por estes motivos, a doutrina maioritária tem considerado que, não obstante a decisão não ser tomada pelo próprio, a escolha de um PCS reflete ainda uma manifestação da autonomia pessoal ${ }^{15}$. Contudo, exclui-se a nomeação das pessoas que intervenham profissionalmente na realização da DAV e na prestação de cuidados de saúde ao paciente (artigo 11.\%/3 da Lei n. ${ }^{\circ}$ 25/2012).

Além desta limitação, deverão opor-se alguns limites ou linhas de orientação à decisão que venha a ser tomada pelo PCS, precisamente para evitar situações de crassa incompatibilidade entre a decisão deste e aquela que seria a vontade do paciente. A nossa lei não prevê tal hipótese, mas o facto de permitir a coexistência simultânea destas duas modalidades de DAV's - como decorre das várias normas que as mencionam reportando-as à mesma situação concreta - pode funcionar como um destes limites para impor barreiras à decisão a proferir pelo PCS.

\subsection{0 testamento vital}

\subsubsection{Conteúdo do testamento vital}

O que a seguir se dirá vale, em boa medida, quer para o testamento vital quer para a decisão manifestada pelo PCS. Porém, é em relação àquele primeiro que se colocam mais complexas questões, uma vez que o seu conteúdo fica completo no momento da respetiva feitura (salvaguardando possíveis modificações e revogações), não sendo suscetível de uma adaptação à medida da situação concreta feita pelo próprio redator do testamento vital, mas apenas da adaptação que seja levada a cabo por via da interpretação

14 O paciente deve obviamente ter o cuidado de escolher alguém que esteja próximo das suas convicções pessoais, o que nem sempre corresponde a um familiar próximo.

15 João Carlos LOUREIRO, "Metáfora do Vegetal...", p. 41; Helena Pereira de MELO, "Directivas...", p. 13; André Gonçalves PEREIRA, O Consentimento Informado..., p. 250, 251; Vera Lúcia RAPOSO, “Directivas Antecipadas de Vontade...”,especialmente p. 178 e 184. 
da equipa médica, na medida em que o teor textual do testamento deixe espaço para tal interpretação. Ou seja, é no testamento vital que o paciente efetivamente plasma o conteúdo da sua vontade, ao passo que na procuração ao PCS apenas se autorize a manifestar uma vontade que seja reportada ao outorgante da procuração, mas sem especificar o conteúdo da mesma, ainda que, segundo nos pareça, lhe possa opor limites.

Ao contrário do que se poderia pensar, o testamento vital (as DAV's no geral) não se destina apenas a recusar tratamentos médicos, embora seja esta a sua forma mais frequente ${ }^{16}$. É o próprio legislador que, ao referir o seu possível conteúdo (de forma não taxativa, pois a enunciação termina com o "nomeadamente") enumera situações nas quais o paciente expressamente requer determinado ato médico ${ }^{17}$.

Assim, o testamento vital pode ser usado para recusar "tratamento de suporte artificial das funções vitais" (artigo 2.\%/2/a da Lei n. ${ }^{\circ}$ 25/2012) e "tratamento inumano, inútil ou desproporcionado no seu quadro clínico" (artigo 2. \%/2/b da Lei n. ${ }^{\circ} 25 / 2012$ ), o que vai totalmente ao encontro das boas práticas estipuladas no Código Deontológico da Ordem dos Médicos (CDOM) e internacionalmente reconhecidas em termos de repúdio do encarniçamento terapêutico.

Outra manifestação da autodeterminação do paciente prende-se com a possibilidade de recusar, por via do testamento vital, "tratamentos que se encontrem em fase experimental” (artigo 2.\%/2/d da Lei n. ${ }^{\circ}$ 25/2012) e para aceitar ou recusar a "participação em programas de investigação científica ou ensaios clínicos" (artigo 2.\%/2/e da Lei n. ${ }^{\circ}$ 25/2012).

Contudo, note-se que o legislador reconhece expressamente que o testamento vital pode igualmente ser utilizada para "receber os cuidados

16 Em particular sobre a recusa das testemunhas de Jeová, Helena Pereira de MELO, "Directivas...", p.7/11, 17/19.

17 Deste elenco legal não faz parte qualquer referência à doação de órgãos, sendo que a omissão do artigo $2 .^{\circ}$ torna-se irrelevante face ao caráter não taxativo da norma. Porém, embora esta seja uma inclusão que tem sido defendida por alguns autores (Jose Luis REQUERO IBAÑEZ, El Testamento Vital..."), cremos que é muito discutível que no ordenamento jurídico pátrio as DAV's possam servir para este efeito atendendo ao regime vigente entre nós no que respeita à doação de órgãos de cadáver (cuja mais recente intervenção legal consta da Lei n. ${ }^{\circ} 36 / 2013$, de 12/06) e ao acolhimento da regra do dissentimento (segundo o qual o cidadão terá que se manifestar quando não queira ser dador, sendo o seu silêncio tomado como voluntarização para a doação). Por força deste quadro legal parece-nos que não terá validade uma hipotética recusa (falamos na recusa porque só esta interessa, já que à partida todos somos dadores) para doação de órgãos plasmada numa DAV, a não ser que a própria lei reconhecedora de efeitos jurídicos às DAV's determinasse o contrário, o que não sucedeu entre nós. Sobre o regime português em matéria de doação de órgãos veja-se José de Faria COSTA, "O Valor do Silêncio do Legislador Penal...", p. 87 ss.; Paula Ribeiro de FARIA, Aspectos Jurídico-Penais dos Transplantes; João Carlos LOUREIRO, Transplantações...; André Gonçalo PEREIRA, "Transplantation of Organs and Tissues'...", p. 55 ss. 
paliativos adequados ao respeito pelo seu direito a uma intervenção global no sofrimento determinado por doença grave ou irreversível, em fase avançada, incluindo uma terapêutica sintomática apropriada" (artigo 2. \%/2/c da Lei n. ${ }^{\circ}$ 25/2012).

Não significa isto que o paciente possa utilizar o testamento vital (ou mesmo o PCS) para impor ao médico um procedimento que de outra forma não seria aplicado. Por mais relevância que se tenha atribuído hoje em dia ao consentimento informado do paciente e à decisão que este tome em matérias atinentes ao seu corpo, vida e saúde, certo é que tal relevância assume um cariz preponderantemente negativo, isto é, como forma de recusar tratamentos, ainda que life saving. Nunca com isto se pretende vincular o médico à aplicação do específico tratamento que o paciente pretenda, uma vez que o profissional de saúde mantém toda a autonomia de decisão terapêutica ínsita à sua profissão. Se porventura o paciente pudesse exigir ao médico, por via de um testamento vital, a aplicação de procedimentos que, caso fossem requeridos de viva voz, estando ele consciente, seriam negados, então, teríamos um regime jurídico privilegiado para os portadores de DAV's (expressamente proibido pelo artigo $10 .^{\circ}$ da Lei n. ${ }^{\circ}$ 25/2012). Além do mais, corríamos o sério risco de empurrar o médico para situações de má prática médica sempre que o paciente requeresse tratamentos que pudessem ser qualificados de encarniçamento terapêutico ${ }^{18}$. "O desejo de tratamentos extraordinários, que em nada adiantarão para o bem-estar do doente ou para a sua longevidade, não vincula o médico"19.

Seja qual for o seu conteúdo, nunca pode a DAV ser motivo de tratamento privilegiado ou prejudicial para o paciente. Este é um princípio geral que já derivaria dos princípios constitucionais gerais (nomeadamente, o princípio da igualdade do artigo $13 .^{\circ}$ da Constituição da República Portuguesa, CRP) e das próprias regras deontológicas da classe médica. Porém, o artigo $10 .^{\circ}$ da Lei n. ${ }^{\circ}$ 25/2012 esclarece, cabalmente, que "[n]inguém pode ser discriminado no acesso a cuidados de saúde ou na subscrição de um contrato de seguro, em virtude de ter ou não outorgado um documento de diretivas antecipadas de vontade", sendo que este princípio, que vale para a existência ou inexistência da DAV, há de igualmente valer para o respetivo conteúdo.

18 Sobre a futilidade terapêutica vide Vera Lúcia RAPOSO, "Directivas Antecipadas de Vontade...", p. 5 e "Entre a Vida e a Morte...", p. 120.

19 Vera Lúcia RAPOSO, "Directivas Antecipadas de Vontade...", p. 176.

Também neste sentido Helena Pereira de MELO, "Directivas...", p. 5: "Neste caso o médico não tem o dever de sujeitar o paciente a um encarniçamento terapêutico que considera trazer-lhe maiores riscos e sofrimentos do que benefícios. O médico tem, aliás e pelo contrário, a obrigação deontológica de não prescrever tratamentos supérfluos, fúteis ou inúteis...”. 


\subsubsection{Redação do testamento vital}

A redação de um testamento vital é matéria que exige especial cuidado e que, por isso mesmo, deve ser acompanhada por um jurista e por um médico, de forma a garantir que a vontade nela plasmada é juridicamente concretizável, medicamente plausível e facilmente compreensível por terceiros, muito em especial pela equipa médica a quem se destina.

Desde logo, é necessário encontrar aqui o difícil equilíbrio entre generalidade e concretude. O testamento vital não pode ser tão geral e abstrato que impeça a apreensão da real vontade do outorgante ${ }^{20}$, cuja tutela é, afinal, a sua função primacial. Assim, o texto não se deve limitar a dizer que o testador "recusa tratamentos fúteis", pois que então deixa em aberto o que é, em seu entendimento, um tratamento fútil, conceito este que apenas em concreto permite concretização ${ }^{21}$. Não significa que um testamento vital que se manifeste nestes termos seja necessariamente recusado pela equipa médica por falta de concretização. Porém, certamente que o outorgante se arrisca a que a sua real vontade não seja devidamente compreendida. Afinal, aquilo que ele considerou na sua mente aquando da redação do testamento vital como "tratamento fútil" pode assim não ser considerado pela equipa médica e vice-versa. Mas, e por outro lado, tão pouco pode o testamento vital ser demasiado específico nas suas disposições, sob pena de vir a ser inútil na prática, porque o paciente nunca se irá encontrar naquela muito particular situação nele prevista.

Aparte testamentos vitais muito específicos e precisos no seu conteúdo (e que, como já vimos, se arriscam a ser inúteis), quase todos eles necessitam de algum tipo de interpretação por parte da equipa médica. O propósito orientador desta tarefa interpretativa deve ser a identificação da real vontade do paciente ao redigir o testamento vital.

Comece por se sublinhar que esta nem sempre será uma tarefa fácil para os seus destinatários, uma vez que, sendo um documento jurídico, não raro comportará noções e termos jurídicos não imediatamente apreensíveis por quem não tenha formação específica na matéria. Daí que seja importante tomar duas cautelas: por um lado, incluir um médico na redação do mesmo, que terá a seu cargo, entre outras importantes funções, a tarefa de tornar o texto apreensível a um profissional de saúde; por outro lado, pedir esclarecimentos interpretativos por parte de um jurista (por exemplo, o departamento jurídico do hospital) quando se trate de documentos de cariz predominantemente técnico-jurídico.

20 Cfr. David RODRÍGUEZ-ARIAS, Una Muerte Razonable..., p. 34/39.

21 O legislador utiliza a expressão "tratamento fútil, inútil ou desproporcionado no seu quadro clínico e de acordo com as boas práticas profissionais" para atribuir ao autor do testamento vital a possibilidade de manifestar qualquer recusa que preencha esta cláusula geral, mas certamente que ao próprio testador se exige um maior grau de especificidade. 
No que respeita à equipa médica cumpre definir quem, no seio da mesma, terá a decisão final quanto à interpretação que melhor colhe ao testamento vital. Tal faculdade há de caber, em primeira mão, ao médico que acompanha o paciente e que seria responsável por colher o seu consentimento informado se aquele estivesse em condições de o fazer, o chamado médico responsável. Porém, caso se suscitem dúvidas de interpretação relevantes quanto ao tratamento a aplicar (por exemplo, porque outros membros da equipa contestam a interpretação que foi dada ao testamento vital), deve a questão ser apresentada (pelo menos se não houver urgência de atuação) ao diretor clínico e à comissão de ética do hospital e mesmo, em última instância, a um tribunal.

\subsubsection{0 consentimento esclarecido materializado no testamento vital}

Uma das mais prementes críticas que podemos dirigir ao atual regime vigente entre nós sobre DAV's é o facto de não impor o aconselhamento por um médico aquando da sua redação. Este óbice suscita particulares cuidados tratando-se de um testamento vital, na medida em que este materializa uma vontade que se pretende definitiva e completa, ao passo que, tratando-se da procuração ao PCS, a sua redação terá que ser sempre, pela própria natureza das coisas, mais genérica e abstrata, pois que será ao PCS que em última instância cabe tomar a decisão concreta quando o momento chegar. De modo que a exigência de consentimento informado é especialmente relevante no caso do testamento vital, supondo-se que face ao PCS este requisito será cumprido no momento em que o procurador tenha que tomar a sua decisão, dado que o médico responsável estará vinculado a cumprir face àquele a exigência de informação exatamente como se se tratasse do próprio paciente.

Contudo, mesmo que se verifique efetivamente a presença de um médico aquando da redação do testamento vital, anda assim nunca o consentimento aí plasmado será totalmente informado. É que a informação possível de transmitir em cenários abstratos nunca será equivalente àquela disponível num cenário concreto. Por outras palavras, o médico poderá explicar ao titular da DAV o significado de determinado estado clínico, o prognóstico expetável em tais situações, os benefícios e malefícios associados em regra aos atos médicos que são aceites ou recusados no testamento vital; porém, escapam a esta informação as particularidades da situação clínica em que aquele efetivamente se poderá vir a encontrar, as quais se poderão revelar decisivas.

Mas isto não significa que o testamento vital viole a exigência legal de consentimento informado. Rectius, não violará quando o autor da DAV tenha sido informado das implicações médicas referentes às decisões plasmadas na DAV, o que, por sua vez, exige o acompanhamento de um médico. 


\subsection{PCS}

\subsubsection{Quem pode ser PCS}

O legislador estabeleceu algumas limitações quanto a quem pode ser nomeado PCS. Assim, para além de requisitos gerais de capacidade a cumprir (maioridade, capacidade para consentir de forma livre e esclarecida e ausência de inabilitação ou interdição, afinal, os mesmos requisitos estipulados para o outorgante no artigo $4 .^{\circ}$, por remissão do . $^{\circ} 2$ do artigo 11 . $^{\circ}$ da Lei n. ${ }^{\circ}$ 25/2012), o legislador fez recair uma proibição sobre os funcionários do RENTEV ou do cartório notarial onde a DAV venha a ser celebrada, à qual acresce uma outra proibição sobre os proprietários e os gestores das entidades que administram ou prestam cuidados de saúde (artigo 11. ${ }^{\circ} 3$ da Lei n. ${ }^{\circ} 25 / 2012$ ) 22 , exceto se estes forem familiares do outorgante (artigo 11.\%/4 da Lei n. ${ }^{\circ}$ 25/2012).

Admite-se ainda que o outorgante nomeie dois PCS's. A intenção não é atribuir-lhes poderes conjuntos de representação (até porque tal solução poderia gerar divergências de opinião e conflitos), mas sim que um deles (o PCS subsidiário) apenas atue na impossibilidade do outro, que será o PCS principal, poder atuar ${ }^{23}$.

O PCS não tem que ser um familiar (bons motivos podem até sugerir que não o seja), mas poderá sê-lo, como expressamente admitido no artigo 11.\%/4 da Lei n. ${ }^{\circ}$ 25/2012. Quando assim ocorra há que distinguir entre a posição desse familiar enquanto atua nessa sua mera qualidade ou, ao invés, quando atua imbuído no papel de PCS. Pois no primeiro caso limitar-se-á a proferir opiniões que o médico poderá utilizar para construir aquela que seria a decisão do paciente caso a pudesse manifestar - o consentimento presumido - mas que o médico não está vinculado a seguir. Já na segunda hipótese a sua decisão terá a mesma força que aquela que seria tomada pelo paciente se o pudesse fazer, logo, assume caráter vinculativo (o que implica uma concomitante alteração ao n. ${ }^{\circ} 2$ do artigo $49 .^{\circ}$ do CDOM, que nos diz que as recusas de tratamento devem ser manifestadas pelo próprio, mas que deve passar a abarcar a possibilidade de as mesmas poderem ser manifestadas por um PCS).

22 Note-se que o legislador apenas se refere expressamente aos "proprietários e gestores", mas cremos que o mesmo deve valer para os efetivos prestadores de cuidados de saúde, pois estes devem ser os recetores de decisão do PCS, não os emissores da mesma.

23 Esta solução terá tentado obviar à hipótese de o paciente nomear um PCS que à data da decisão não esteja em condições de decidir (morte, doença, situação de incontactabilidade) ou se recuse a fazê-lo (sobre esta última situação, Martín PECOY TAQUE, "Testamento Vital...", p. 66). 


\subsubsection{Força da decisão manifestada pelo PCS}

Tal como já deixámos referido, a decisão do PCS defronta-se com os requisitos de validade e de vinculatividade que valem no geral para as DAV's (sendo certo que, pela própria natureza das coisas, nem todos lhe são aplicáveis).

Porém, para além das regras gerais do artigo $3 .^{\circ}$ e seguintes, existem ainda regras específicas deste instituto.

De acordo com o artigo $13 .{ }^{\circ} / 1$ da Lei n. ${ }^{\circ}$ 25/2012, a decisão manifestada pelo PCS, dentro dos limites que tenham sido estabelecidos aos seus poderes de representação, deve ser respeitada como se houvesse sido manifestada pelo próprio paciente (logo, não se confunde com a decisão que teria sido expressa por aquela mesma pessoa caso fosse ouvida na sua mera qualidade de familiar ou amigo). A expressão usada pelo legislador - "dentro dos limites dos poderes representativos que lhe competem" - não esclarece cabalmente que limites serão esses. Será que o legislador se refere aos limites gerais colocados pelo ordenamento jurídico às decisões em matéria de cuidados de saúde, nomeadamente, mediante a proibição de certas práticas eutanásicas ${ }^{24}$ ? Ou aos limites específicos determinados pela Lei $n .^{\circ}$ 25/2012, que expressamente comina que o PCS apenas goza de poderes de representação "em matéria de cuidados de saúde" (n. ${ }^{\circ} 1$ do artigo $12 .^{\circ}$ da Lei n. ${ }^{\circ}$ 25/2012)? Ou será que pretende igualmente fazer referência aos limites que venham a ser impostos pelo próprio outorgante à decisão do PCS na procuração (supondo que lhe é permitido incluir limitações dessa índole, como nos parece que efetivamente é)? Segundo cremos, o legislador pretende abarcar estas três modalidades de limitações, de tal forma que só a decisão do PCS que respeite esta tríade será tida em conta como decisão vinculativa.

Outra possível barreira à decisão do PCS a ter em consideração prende-se com a eventual existência de um testamento vital estabelecido pelo mesmo paciente, hipótese expressamente prevista no n. $^{\circ} 2$ do artigo $13 .^{\circ}$ da Lei n. ${ }^{\circ}$ $25 / 2012$, pois que em tal caso prevalecerá a decisão manifestada no testamento vital, na medida em que este cumpra todos os requisitos legalmente estabelecidos para a sua validade e eficácia.

A qualquer momento o paciente pode revogar a procuração ao seu PCS (n. ${ }^{\circ} 1$ do artigo $14 .^{\circ}$ da Lei.$^{\circ}{ }^{2}$ 25/2012), mas também pode ser renunciada por este último, devendo em tal caso comunicar por escrito a sua decisão ao outorgante (n. ${ }^{\circ} 2$ do artigo $14 .^{\circ}$ da Lei n. ${ }^{\circ} 25 / 2012$ ).

24 Apenas de certas práticas eutanásicas, pois, como já deixámos expresso, nem todas as formas de eutanásia são punidas entre nós (Vera Lúcia RAPOSO, "Directivas Antecipadas de Vontade...", p. 185 ss. e "Entre a Vida e a Morte...", p. 125 ss.). 


\subsubsection{Redação da procuração ao PCS}

A Lei n. ${ }^{\circ}$ 25/2012 não comina qualquer regra específica quanto à redação da PCS, isto é, ao seu conteúdo.

Nomeadamente, não esclarece um ponto que nos parece crucial: pode (ou mesmo deve) o outorgante estabelecer barreiras/limites à vontade que venha a ser manifestada pelo PCS por si escolhido?

Porém, e tendo em consideração que em última análise se trata de uma procuração, ainda que para um campo de atuação muito específico e delimitado, deve aplicar-se a regra geral que vale para as demais procurações ${ }^{25}$, o que leva a admitir que o outorgante nela inclua os limites e condições que assim entender.

Note-se que esta deve ser uma faculdade e não uma obrigação. Ou seja, não deve ser recusada a procuração que se limite a atribuir a uma pessoa determinada poderes de representação em matérias relacionadas com a prestação de cuidados de saúde. Não apenas porque nada na Lei n. ${ }^{\circ}$ 25/2012 implica semelhante conclusão, mas também porque pode ser o próprio outorgante a pretender que o PCS decida a situação concreta sem qualquer freio colocado a priori.

Contudo, tudo aconselha a que a procuração passada ao PCS inclua tais condicionantes e limitações, atendendo aos perigos que podem advir (como em qualquer outra matéria, mas com particular enfase neste campo) da concessão de uma margem de manobra demasiado ampla ao PCS. Neste domínio revela-se crucial a intervenção do notário ou do funcionário do RENTEV no sentido de aconselhar o outorgante a delimitar de forma eficaz possíveis abusos decisórios por parte do $\mathrm{PCS}^{26}$.

\section{Efetividade das DAV's}

\subsection{Consequências do reconhecimento da vinculatividade das DAV's}

O reconhecimento da vinculatividade das DAV's pretende dar satisfação a uma série de apreensões e necessidades que nos últimos anos têm animado o debate jurídico e a relação médico-paciente.

25 Sem que isto signifique que estas procurações devam reger-se na integra pelo regime geral das procurações, pois que sempre há que ter em consideração as particularidades deste domínio específico. Contudo, poderá haver situações em que tais particularidades não obviem à aplicação do regime geral.

26 Quando o PCS ultrapasse os poderes que lhe foram conferidos pelo outorgante na procuração incorrerá em responsabilidade civil perante aquele (artigos $258 .^{\circ}, 269 .^{\circ}$ e $1161 . \%$ a do CC) e pode mesmo arriscar-se a responsabilidade criminal. 
Por um lado, permitem ao paciente inconsciente recusar ou aceitar atos médicos e, desta forma, cumprir a exigência de consentimento do paciente, bem como os direitos a esta associados, nomeadamente o direito à integridade pessoal e à autodeterminação, enquanto manifestações do direito ao desenvolvimento da personalidade.

Mas, e por outro lado, apresentam também importantes mais-valias para o profissional de saúde, até ao momento atormentado com a definição daquela que lhe parecesse ser a decisão médica mais acertada para aquele doente, do ponto de vista do próprio. Ora, esta é uma tarefa excecionalmente difícil de levar a efeito, para além de excessivamente onerosa em termos éticos e morais. Atendendo ao clima de litigância a que se vem assistindo nos últimos anos, inclusive entre nós, muitos médicos poderiam tender a preocupar-se mais com a averiguação dessa suposta vontade do paciente do que com a administração dos cuidados de saúde a que o paciente tem direito. Nesta perspetiva as DAV's revelam-se um instrumento essencial para desonerar o médico de uma função que não lhe cabe a ele, mas sim ao próprio paciente, permitindo-lhe assim concentrar-se naquele que é o núcleo da sua profissão: o exercício da medicina de acordo com o melhor interesse (subjetivo) do paciente.

Esta será também uma forma de responsabilizar o paciente pela gestão dos atos médicos que lhe são praticados. É que o paternalismo médico que tanto temos criticado não foi apenas alimentado pelos médicos, mas igualmente por alguns pacientes que preferem que sejam aqueles outros a assumir todas as consequências dos cuidados médicos que lhes são prestados.

Não significa isto que as DAV's estejam isentas de problemas e dificuldades. Na verdade, a atribuição de caráter vinculativo às DAV's acarreta consigo novos desafios, na medida em que o profissional de saúde se verá confrontado com a interpretação ${ }^{27}$ de DAV's nem sempre claras e evidentes, com possíveis vícios da DAV que possam obstar ao seu caráter vinculativo e que se espera que o médico identifique, enfim, com toda uma panóplia de novos reptos até então desconhecidos dos profissionais de saúde. Contudo, cada vez mais a atividade médica anda associada a exigências jurídicas e éticas, sendo que a matéria ligada ao consentimento informado em geral, e às DAV's em particular, é uma das que mais se presta à colaboração conjunta entre estes domínios e saberes, o que minorará eventuais dificuldades com que o médico se venha a defrontar neste ensejo.

27 Sobre os problemas suscitados pela interpretação de uma DAV, especialmente do testamento vital, Jose Luis REQUERO IBAÑEZ, "El Testamento Vital...". 


\subsection{A vinculatividade das DAV's no ordenamento jurídico português antes de 2012}

Não se pode dizer que o ordenamento jurídico português anterior à Lei n. ${ }^{\circ}$ 25/2012 repudiasse as DAV's (em qualquer das suas duas formas). Simplesmente, não lhes atribuía poder vinculativo.

De facto, o artigo 156. ${ }^{\circ}$ do Código Penal (CP), depois de exigir a presença de um prévio consentimento do paciente para qualquer ato médico (n. $\left.{ }^{\circ} 1\right)$, admite a possibilidade de o paciente não estar em condições de o prestar (n. $\left.{ }^{\circ} 2\right)$, permitindo então ao médico recorrer ao consentimento presumido do paciente. A lei não fornece indicações sobre a forma de orientar tal presunção, mas tudo indica que o médico se poderá socorrer de tudo o que lhe permita aceder à genuína vontade do paciente - note-se bem, aquilo que o paciente decidiria (critério subjetivo) e não aquilo que seja racionalmente o melhor para aquele paciente (critério objetivo) -, desde escritos prévios da sua parte até a opinião de amigos e familiares e relatos das crenças e convicções pessoais.

Por conseguinte, as DAV's deveriam ser tidas em consideração pelo médico, à luz do disposto no n. ${ }^{\circ} 2$ deste artigo $156 .^{\circ}$ do CP. Mas ter em consideração não é o mesmo que respeitar. Logo, o médico violaria esta norma caso a DAV lhe fosse apresentada e o médico a ignorasse por completo, uma vez que estaria a desdenhar um elemento decisivo para a delineação do consentimento presumido do paciente. Porém, se após analisada a DAV o médico decidisse rejeitar o seu conteúdo - por entender que este não corresponde a genuína vontade atual do paciente, por exemplo - não estaria a violar norma alguma.

De certa forma este é o regime ainda presente no CDOM, pois quando o artigo $46 . \% / 2$ determina que "[s]e houver uma directiva escrita pelo doente exprimindo a sua vontade, o médico deve tê-la em conta quando aplicável à situação em causa". Uma vez que esta disposição não está em conformidade com a atual Lei $n .^{\circ} 25 / 2012$, tudo aconselha a que a mesma seja devidamente adequada ao novo regime legal.

\subsection{Formalidades da vinculatividade das DAV's}

As formalidades a respeitar pelas DAV's - ao que parece, em qualquer das suas formas - aparecem tratadas no artigo $3 .^{\circ}$ da Lei n. ${ }^{\circ} 25 / 2012$, que estipula certas condições quanto ao documento no qual se concretiza o testamento vital e a procuração que atribui poderes ao PCS.

A dita norma determina que estas devem assumir a forma escrita e ser presencialmente assinadas perante um notário ou perante um funcionário do RENTEV. Sublinhe-se que não é necessário depositar a DAV no RENTEV, pois que tal registo apenas visa conferir maior publicidade à DAV, não sendo condição da sua validade nem da sua eficácia. 
Não se impõe a adoção de um formulário específico ${ }^{28}$, mas há requisitos quanto ao respetivo conteúdo (artigo 3.\%1 da Lei n. ${ }^{\circ}$ 25/2012), o qual deve incluir a identificação completa do outorgante (a lei nada diz quanto ao PCS, mas tudo indica que da procuração deve também constar a identificação completa deste, por ser um requisito geral das procurações); o lugar, data e hora da assinatura; os estados clínicos que a DAV tem em vista (porém, no que respeita ao PCS pode-se questionar se também este deve estar necessariamente limitado a decidir só em certos estados clínicos, sendo certo que a margem de manobra e flexibilidade que lhe é reconhecida como forma de contornar a rigidez do testamento vital há de igualmente permitir uma interpretação dos estados clínicos descritos na procuração lata e adequada ao caso concreto) e as instruções (no sentido de autorizar ou proibir determinado ato) para cada um desses estados clínicos; e eventuais declarações de renovação, alteração ou revogação.

Outro leque de requisitos formais prende-se com a legitimidade do outorgante (artigo $4 .^{\circ}$ da Lei n. ${ }^{\circ}$ 25/2012), o qual deve ser maior de idade (logo, parece excluir menores emancipados ${ }^{29}$ ), capaz de dar o seu consentimento “consciente, livre e esclarecido" e, por maioria de razão, não se encontrar inabilitado ou interdito em razão de anomalia psíquica.

Note-se que a Lei n. ${ }^{\circ}$ 25/2012 não exige o acompanhamento por parte de um médico, não obstante prever que o mesmo possa ocorrer e, em tal caso, sugerir que a identificação e assinatura do médico constem do documento ${ }^{30}$ (artigo 3. $\%$ /2 da Lei n. ${ }^{\circ}$ 25/2012). Ter-nos-ia parecido mais avisado impor a participação de um médico que esclarecesse o paciente sobre as exatas implicações dos estados clínicos referidos na DAV, bem como sobre as consequências dos atos médicos que o outorgante tenciona aceitar ou recusar ${ }^{31}$. Mal se compreende

28 Embora, e segundo o n. ${ }^{\circ} 4$ do artigo $4 .^{\circ}$ da Lei n. ${ }^{\circ}$ 25/2012, venha a ser disponibilizado um formulário modelo (não obrigatório, sublinhe-se).

29 Note-se que a questão da maioridade para efeitos de prestar consentimento para atos médicos está longe de obter uma resposta consensual, na medida em que, enquanto o ordenamento civil estipula os 18 anos como idade a partir da qual se dispõe de capacidade jurídica, isto é, de capacidade para assumir direitos e obrigações (artigos 122. ${ }^{\circ}$ e seguintes do CC), já o ordenamento penal atribui a faculdade de prestar consentimento jurídico-criminalmente atendível aos 16 anos (artigo 38.\%/3 do CP), desde que o sujeito possua "o discernimento necessário para avaliar o seu sentido e alcance no momento em que o presta”. O artigo 4. ${ }^{\circ}$ da Lei n. ${ }^{\circ}$ 25/2012 reporta-se, ao que tudo indica, à maioridade civil, isto é, aos 18 anos.

$30 \mathrm{O}$ que a seguir se dirá vale essencialmente para o testamento vital, pois que é óbvio que no caso do PCS a informação necessária e o consequente aconselhamento médico serão fornecidos a este no momento em que a decisão se imponha; porém, caso se entenda, como nos parece, que a ideia do legislador é que também na procuração que fundamenta os poderes do PCS o outorgante proceda à delimitação dos estados clínicos a que a referida procuração se dirige, então, também aí esta salvaguarda mantém a sua valência.

31 Já assim o tínhamos defendido em Vera Lúcia RAPOSO, “Directivas Antecipadas”, p. 179. 
que se considere a vontade plasmada no testamento vital como esclarecida (como o impõe o artigo $157 .^{\circ}$ do CP face a qualquer decisão do paciente, esclarecimento que apenas é dispensado no consentimento presumido, pela natureza própria das coisas, sendo que a vontade expressa no testamento vital equivale ao consentimento expresso, não ao presumido ${ }^{32}$ ) quando não há garantia de que o paciente efetivamente compreenda as consequências médicas das respetivas decisões.

\subsection{Confirmação da existência da DAV}

A melhor forma de garantir que a DAV é efetivamente conhecida pelos respetivos destinatários seria impor o seu registo obrigatório, o qual pudesse ser acedido informaticamente em qualquer ponto do país (e, eventualmente, da Europa). Porém, o nosso legislador entendeu de forma diferente e optou por considerar tal registo facultativo (artigo 16. $\% 1$ da Lei n. ${ }^{\circ} 25 / 2012$ ), o que pode causar graves dificuldades no momento de a equipa médica perceber se o paciente é ou não portador de uma $\mathrm{DAV}^{33}$.

Quando o RENTEV (artigo 15..$^{\circ}$ da Lei n. ${ }^{\circ}$ 25/2012) esteja a funcionar devidamente o primeiro passo que qualquer prestador de cuidados de saúde deve fazer é averiguar, junto do mesmo, se o paciente que tem em mãos é portador de uma DAV. Porém, e uma vez que o facto de esta não estar registada não significa que não exista, deve ainda averiguar junto dos amigos e familiares do paciente sobre a eventual existência da mesma.

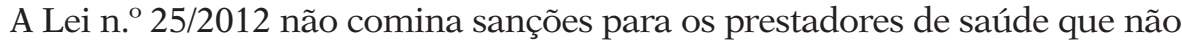
tomem medidas para averiguar se o paciente celebrou ou não uma DAV. Porém, se a omissão de tais medidas passar impune esta poderá ser uma via relativamente simples de contornar a eficácia vinculativa que a lei reconhece à DAV nos casos em que esta não é voluntariamente apresentada à equipa médica (pelos acompanhantes do paciente ou pelo próprio enquanto ainda estava consciente).

É a própria lei que demanda ao prestador de cuidados de saúde que confirme, junto do RENTEV, a existência de uma DAV (artigo 17.\%1 da Lei n. ${ }^{\circ}$ 25/2012). Por conseguinte, deve entender-se que a omissão de qualquer medida destinada a averiguar da eventual existência de uma DAV equivale a uma atuação sem consentimento do paciente, prevista e punida no artigo 156. do CP, de que mais à frente falaremos.

32 Ou seja, embora o consentimento manifestado na DAV pretenda evitar o recurso ao consentimento presumido, ele próprio é equiparado ao consentimento expresso.

33 De certa forma, é como se o registo funcionasse como um ónus para o paciente, isto é, não é obrigatório para efeitos de eficácia ou validade da DAV, nem o outorgante sofre qualquer sanção se não a registar, porém, corre o sério risco de esta não ser atendida por desconhecimento razoável da mesma por parte da equipa médica. 
Contudo, tão pouco será de exigir à equipa médica que tome todas as providências imagináveis para averiguar da existência de uma DAV, sob pena de impedir o médico de desempenhar a função que lhes é atribuída.

Em suma, a consulta do RENTEV deve impor-se em qualquer situação, exceto em casos de urgência que não se compadeçam com tal demora, como de resto vem previsto no artigo n. ${ }^{\circ} 4$ do artigo $6 .^{\circ}$ da Lei n. ${ }^{\circ}$ 25/2012 ${ }^{34}$. Aparte estes casos de extrema urgência, as demais medidas a tomar dependem da situação concreta. Assim, se os familiares e amigos estão presentes não se vislumbra motivo para não os questionar acerca de uma eventual DAV. Porém, se o paciente estiver desacompanhado e o contato com familiares/amigos não se revelar fácil, já nos parece que não será exigível ao médico que este se lance num processo de indagações ${ }^{35}$.

Aliás, o próprio legislador parece ter colocado o encargo de divulgar a DAV sobre o paciente e seus acompanhantes, ao invés de incumbir a equipa médica de investigar a sua existência, como se conclui a partir da redação do n. ${ }^{\circ} 1$ do artigo 6. ${ }^{\circ}$ da Lei n. ${ }^{\circ}$ 25/2012: "[s]e constar do RENTEV um documento de diretivas antecipadas de vontade, ou se este for entregue à equipa responsável pela prestação de cuidados de saúde pelo outorgante ou pelo procurador de cuidados de saúde, esta deve respeitar o seu conteúdo".

\subsection{Força vinculativa das DAV's}

\subsubsection{Requisitos de vinculatividade das DAV's}

Uma das alterações mais substanciais introduzidas pela Lei n. ${ }^{\circ}$ 25/2012 no ordenamento jurídico pátrio prende-se precisamente com a atribuição de poder vinculativo às DAV's ${ }^{36}$.

O artigo 6.\% da Lei n. ${ }^{\circ}$ 25/2012 começa por dizer que se "deve respeitar o seu conteúdo", o que não pode ser tomado como uma mera orientação aos destinatários da DAV. Significa que a DAV deve ser cumprida pelo médico, sob pena de responsabilidade civil e/ou criminal, exatamente nos mesmos

34 O que pode isentar as equipas de INEM de considerar o conteúdo de eventuais DAV's, ainda que tudo dependa da urgência da situação concreta.

35 Uma questão da qual não iremos tratar aqui, mas que não deixa de ser extremamente relevante (até porque não dispõe de tratamento legal), é a de saber se o testamento vital deve ou não assumir caráter secreto e, assim sendo, quem tem legitimidade para a ele aceder, nomeadamente, em que termos pode o médico tomar conhecimento de testamentos vitais registados num consultório notarial.

36 Manifestando-se veemente contra o seu caráter vinculativo, Teresa Quintela de BRITO, "Interrupção de Alimentação...", p. 576 ss. 
termos em que responderia caso atuasse contra a vontade expressamente manifestada por um paciente consciente.

Porém, certamente que esta vinculatividade apenas assiste às DAV's que cumpram os requisitos legalmente $\operatorname{cominados}^{37,38}$.

Desde logo, os requisitos formais acima apontados e referidos no artigo 3. . . Assim, não é vinculativa a DAV que não contiver uma assinatura presencialmente reconhecida pelo notário ou pelo funcionário do RENTEV, nem a identificação completa do outorgante (pela nossa parte, defendemos o mesmo em relação à identificação do PCS), nem o lugar/data/hora da assinatura, nem a descrição das situações clínicas e das respetivas instruções, ou que seja omissa quanto a declarações de renovação/alteração/revogação entretanto existentes, ou ainda se o outorgante é menor, incapaz ou inabilitado ou se encontra, por qualquer outro motivo, impedido de expressar um consentimento esclarecido.

Uma nota se impõe quanto à compressão do requisito atinente à descrição da situação clínica. Pois não basta identificá-la em termos gerais ou descrevê-la com um teor dúbio, de tal forma que não seja percetível à equipa médica o estado de saúde que o outorgante tinha efetivamente em vista, nomeadamente, se corresponde ou não àquele que agora o assaca. $\mathrm{O}$ mesmo vale para as instruções cominadas na DAV, as quais devem igualmente ser evidente e sem margem para dúvidas de interpretação. É a própria Lei n. ${ }^{\circ}$ 25/2012 que, no seu artigo 5.\%, afasta o carácter vinculativo da DAV em que "o outorgante não tenha expressado, clara e inequivocamente, a sua vontade”.

Este mesmo artigo 5. ${ }^{\circ}$ da Lei n. ${ }^{\circ}$ 25/2012 (que se reporta a DAV consideradas nulas, logo, inexistentes) dispensa igualmente a equipa médica de cumprir o disposto na DAV quando o conteúdo da mesma seja contrário à lei, à ordem pública ou às boas práticas (5.\%a). Por "lei" há-de entender-se qualquer forma legal e traduzida em qualquer diploma, pelo que mal se compreende que logo de seguida $(5 . \%)$ o legislador especifique o caso em que o respeito pela DAV preencha os tipos de ilícitos dos artigos $134 .^{\circ}$ e $135 .^{\circ}$ do $\mathrm{CP}$, os quais se referem ao homicídio a pedido da vítima e ao incitamento ou ajuda ao suicídio. Esta referência é desnecessária porque já estava incluída na proibição de contrariedade à lei, pelo que só se justifica porque o legislador pretendeu reforçar a ideia de que a DAV se destina a recusar um tratamento que poderia atrasar, ou mesmo impedir, um processo de morte natural (no

37 Não os cumprindo, pode questionar-se se o vício que apenas afete determinadas cláusulas deixa incólume a vinculatividade das restantes, um pouco como sucede nos negócios jurídicos, em que a ilicitude de uma cláusula permite a redução do negócio e a consequente operatividade das cláusulas lícitas.

38 Contudo, o facto de uma DAV com um vício formal não assumir força vinculativa não impede que o seu conteúdo (supondo que o vício não o afeta) não possa, e mesmo deva, ser tido em consideração para efeitos de aferir o consentimento presumido do paciente. 
sentido de morte provocada por doença) já iniciado, mas nunca a introduzir uma nova causa de morte. A referência à ordem pública pode revelar-se dúbia, dada que se trata de um conceito indeterminado. Numa sociedade laica, plúrima de valores e multidimensional, parece que esta expressão não pode ter outro conteúdo senão o que derive do próprio ordenamento criminal. Significa isto que serão contrárias à ordem pública as estipulações da DAV que possam conduzir à prática de um crime. Mais fácil se revela a interpretação da contrariedade às boas práticas, as quais traduzem as leges artis próprias do exercício da medicina, essencialmente acolhidas no CDOM, mas também em guidelines, protocolos e outros documentos próprios da prática médica.

O artigo 6..$^{\circ}$ da Lei n. ${ }^{\circ}$ 25/2012 acrescenta mais algumas circunstâncias igualmente capazes de afastar a força da DAV, ainda que estas sejam de muito subjetiva apreciação, pelo que se antevê que venham a suscitar algumas dúvidas entre os profissionais de saúde e alimentar a litigância judicial. A grande distinção face aos requisitos previamente referidos é que, enquanto a avaliação do respeito por aqueles outros cabe ao notário ou ao funcionário do RENTEV (de acordo com o que à frente se dirá), já a aferição dos pressupostos descritos neste artigo $6 .^{\circ}$ apenas pode caber ao médico, dado que tal análise somente se pode colocar no momento da efetiva prestação de cuidados de saúde.

Assim, o artigo 6.\%/2/a da Lei n. ${ }^{\circ}$ 25/2012 dispõe que o médico não está obrigado a respeitar a DAV quando "se comprove que o outorgante não deseja mantê-la”. Mas em que circunstâncias se pode dar por verificado tal pressuposto? Será que basta uma avaliação casuística do médico, porventura fundada naquilo que ele próprio considera, à luz das suas valorações pessoais, ser o melhor para o paciente? Será que basta que um familiar venha contestar a decisão da DAV para se concluir que o paciente já terá mudado de opinião? Certamente que se haverá de exigir uma convicção minimamente consistente de que efetivamente se operou uma modificação da vontade do paciente, não bastando a mera alegação genérica de que, mesmo aqueles que em dado momento repudiaram certas condições de vida, hoje, à beira da morte, conformam-se com elas, por mais duras que sejam. Assim, o funcionamento desta cláusula terá que ser verdadeiramente excecional, sob pena de banalizar o repúdio das DAV's.

Por outro lado, a alínea b) do artigo 6. ${ }^{\circ}$ da Lei n. ${ }^{\circ} 25 / 2012$ descreve as situações em que "se revela evidente desatualização da vontade do outorgante face ao progresso dos meios terapêuticos, entretanto verificado”. Embora de cariz igualmente subjetivo, esta pressuposição é, apesar de tudo, mais facilmente percetível na prática do que a anterior. Suponha-se, por exemplo, que o paciente recusara medidas de suporte vital porque à data da feitura da DAV o estado clínico em causa - que referiu na sua DAV e no qual hoje se encontra efetivamente - não apresentava qualquer esperança de recuperação, 
sendo que hoje, uma dezena de anos mais tarde, a ciência evolui a tal ponto que é perfeitamente expetável que pacientes naquelas condições venham a recuperar na íntegra ${ }^{39}$. Porém, a evidência presente neste relato não é transponível para muitos outros cenários com que na prática o prestador de cuidados de saúde se poderá confrontar e nos quais a decisão a tomar poderá revelar-se menos nítida. Assim, onde se traça a fronteira entre o que é uma vontade desatualizada face ao estado atual da técnica? Que fazer quando aquele estado clínico era na altura de redação da DAV totalmente irrecuperável mas hoje a medicina oferece possibilidades de recuperação, mas apenas cerca de 70\% de possibilidades? Qual a "percentagem de progresso científico" que se deve verificar para atestar a desatualização? Ou então imagine-se que, apesar de existir hodiernamente uma possibilidade de recuperação à data inexistente, esta não é total, pelo que o paciente sempre terá que passar o resto da vida numa cadeira de rodas ou sujeito a tratamentos invasivos? O legislador não forneceu ao médico qualquer critério que o auxilie neste tipo de avaliações e, porventura, nem o poderia fazer, dado que qualquer apreciação abstrata e a priori ficará sempre aquém das particularidades do caso concreto.

Finalmente, a última hipótese prevista neste artigo 6.\%/2 da Lei n. ${ }^{\circ}$ 25/2012 diz respeito às DAV's que "não correspondam às circunstâncias de facto que o outorgante previu no momento da sua assinatura" (6.\%/2/c). Esta expressão não é a mais feliz, dado que parece dar a entender que de novo nos reportamos aos casos em que o contexto tido em mente pelo outorgante entretanto se alterou por força de novos avanços científicos, o que faria coincidir esta previsão da alínea c) com aquela outra prevista na alínea b). De modo que resta concluir que mediante tal previsão quer o legislador referir-se às situações em que seja detetável um vício na forma como o outorgante manifestou a sua decisão, de tal modo que a vontade por si expressa na forma escrita não corresponde à vontade que tinha em mente.

Qualquer das hipóteses previstas neste artigo 6.\%/2 da Lei n. . 25/2012 se reporta a cenários que carecem sempre de uma avaliação concreta e casuística por parte da equipa médica, eventualmente auxiliada por juristas ou pela comissão de ética hospitalar, precisamente devido à complexidade das previsões aqui descritas.

O legislador não contempla, como outra causa de desvinculação à decisão manifestada na DAV, o caso de documentos de teor dúbio e incerto. Sempre

39 De facto, apesar da obrigação de renovações sucessivas, pode suceder que estas se limitem a confirmar a redação inicial da DAV, sem que o paciente pondere verdadeiramente no conteúdo da mesma a cada renovação. Logo, é possível que o paciente tenha em conta evidências científicas existentes vários anos antes e que não sejam tão recentes, perigo particularmente premente devido ao facto de Lei n. $^{\circ}$ 25/2012 não impor um aconselhamento médico, nem aquando da redação adicional nem, muito menos, da sua renovação. 
se poderá dizer que a imposição da presença de um notário ou funcionário do RENTEV permitirá obviar a essa hipótese, porém, a participação de um médico parece-nos imprescindível para garantir DAV’s claras e não contraditórias (para além de assegurar a prestação da necessária informação ao paciente), requisito este não exigido pela Lei n. ${ }^{\circ}$ 25/2012. Mas é óbvio que vale neste ensejo a regra que vale em geral para qualquer documento jurídico quanto às exigências de clareza.

As situações supra descritas reportam-se a circunstâncias inerentes à DAV (que não necessariamente a um vicio ou ilegalidade), mas a estas se acrescentam ainda outras que nada têm a ver com a mesma.

É o que sucede quando a vontade que o paciente expressa na DAV atenta flagrantemente contra as convicções pessoais e éticas do médico, podendo então este invocar o seu direito à objeção de consciência ${ }^{40}$ (artigo 9. ${ }^{\circ}$ da Lei n. ${ }^{\circ}$ 25/2012), devendo em tal caso referir no processo clínico do paciente quais as disposições da DAV que impedem a continuação do acompanhamento clínico pela sua parte. Porém, uma vez que o paciente não poderá ser discriminado pelo facto de ser portador de uma DAV (como sublinhado no artigo $10 .^{\circ}$ da Lei n. ${ }^{\circ}$ 25/2012), a instituição hospitalar onde o incidente se desenrole fica vinculada a providenciar outro profissional de saúde que preste os serviços médicos requeridos na DAV, ainda que seja numa outra instituição de saúde.

Uma outra hipótese em que se afasta o dever de cumprir o disposto na DAV diz respeito a situações de urgência em que a procura de uma DAV e sua análise façam perigar a vida do paciente (artigo 6.\%/4 da Lei n. ${ }^{\circ}$ 25/2012).

\subsubsection{0 controlo da legalidade da DAV}

A aferição do cumprimento dos supra descritos requisitos cabe, segundo vemos as coisas, ao notário ou ao funcionário do RENTEV, que devem aconselhar o outorgante no sentido de suprir as faltas ou omissões detetadas no documento. O legislador não especifica o que sucede caso tais vícios não sejam sanados. A letra da lei parece indicar que os mesmos não servirão de impedimento ao reconhecimento notarial da assinatura, uma vez que, em bom rigor, o artigo 3. /1 da Lei n. ${ }^{\circ}$ 25/2012 apenas confere a estas entidades a função/poder de reconhecimento presencial da assinatura, mas não poder para aquilatar do respeito pelos demais requisitos legais e, consequentemente, recusar o reconhecimento oficial do documento. O que sucede é que a DAV será desprovida de eficácia vinculativa (ainda que possa ser usada como um dos vários indícios a ter em conta pela equipa médica para efeitos de delimitar o consentimento presumido do paciente). Porém, esta não nos parece a solução mais acertada.

40 Morten MAGELSSEN, "When Should...", p. 18/21 e 
Merece algumas reflexões a nossa tese de que o cumprimento da maior parte destes requisitos deve estar a cargo das entidades a quem a lei incumbe proceder ao reconhecimento presencial da assinatura do outorgante (artigo 3.\%/1 da Lei n. ${ }^{\circ}$ 25/2012). Em bom rigor, o legislador apenas lhes cometeu este encargo, porém, seria incongruente fazer intervir uma autoridade pública para simplesmente certificar a identidade de quem assina o documento, quando a referida entidade dispõe dos conhecimentos necessários para verificar a legalidade da DAV. Esta intervenção é particularmente desejável na medida em que o seu objetivo não será apenas barrar uma DAV mas, bem mais do que isso, aconselhar o respetivo outorgante quanto à forma de cumprir os requisitos legalmente exigidos e assim permitir que a DAV venha a ser devidamente respeitada. Porém, seria desejável que o legislador tivesse explicitado estas competências na Lei n. ${ }^{\circ}$ 25/2012, sob pena de aqueles não se entenderem competentes para desempenhar tais funções.

De qualquer forma, o controlo que venha a ser efetuado pelo notário ou pelo funcionário do RENTEV apenas pode aquilatar do respeito pelo ordenamento jurídico. Em contrapartida, outros dos possíveis vícios das DAV's apenas poderão ser avaliados pelo médico que tenha a seu cargo o paciente e, por conseguinte, a quem incumba executar (ou não) a DAV. É o que sucede, por exemplo, com o aparecimento de novos avanços científicos ou com a contrariedade do disposto na DAV face áquilo que se entenda ser a genuína vontade do paciente naquele momento.

O RENTEV é a entidade encarregue de "rececionar, registar, organizar e manter atualizada, quanto aos cidadãos nacionais, estrangeiros e apátridas residentes em Portugal, a informação e documentação" relativa aos testamentos vitais e às procurações passadas aos $\mathrm{PCS}^{\prime} \mathrm{s}^{41}$ (artigo 15.\%/1 da Lei n. ${ }^{\circ}$ 25/2012).

Não é liquido que o RENTEV disponha de competências em sede de fiscalização do conteúdo da DAV's e do respeito pelas formalidades relativas à sua celebração aquando do registo.

Tal como já sublinhámos, o artigo 3.\%/1 da Lei n. ${ }^{\circ}$ 25/2012 é assaz dúbio para este efeito. A norma determina que um dos requisitos a cumprir pelo outorgante da DAV é que esta seja assinada presencialmente perante notário ou perante funcionário do RENTEV, mas sem atribuir expressamente a nenhum deles poderes de fiscalização. Porém, é incongruente que estas entidades se limitem a verificar qual a identidade do outorgante que assina o documento quando qualquer deles está em posição privilegiada para aferir o cumprimento

41 Não obstante a designação deste órgão fazer apenas apelo ao registo de testamentos vitais, a Lei n. ${ }^{\circ}$ 25/2012 atribui-lhe funções de registo em relação às procurações ao PCS.

Todavia, até hoje o RENTEV ainda não foi criado, pelo que o registo das DAV's anda não é uma possibilidade efetivável. 
dos requisitos legalmente estipulados, pelo menos aqueles referidos nos artigos 3. $\% 1,4 .^{\circ}$ e $5 .^{\circ}$ da Lei n..$^{\circ}$ 25/2012. Desde logo, note-se que em termos temporais (quase uma espécie de economia processual) o notário e o funcionário do RENTEV intervém num momento particularmente propício para confirmar que da DAV constam todos os dados referidos no n. ${ }^{\circ} 2$ do artigo $3 .^{\circ}$ da Lei n. ${ }^{\circ} 25 / 2012$, nomeadamente porque podem nesse momento chamar a atenção do outorgante para alguma omissão relevante, de forma a que este proceda às necessárias correções. Por outro lado, estas duas entidades estarão bem mais credenciadas para aferir alguns dos requisitos do que estará o médico que se venha a defrontar com a DAV, tais como, por exemplo, a capacidade do outorgante à data da sua feitura ou a sua contrariedade à lei e à ordem pública, pois que certamente disporá de conhecimentos jurídicos que escapam ao profissional de saúde.

Porém, após a celebração e assinatura da DAV, parece que o RENTEV não poderá recusar o registo da mesma por falta de algum dos requisitos determinados para a sua validade. Isto porque se supõe que o cumprimento de tais requisitos deve ser aferido no momento da sua celebração (por um notário ou por um funcionário desse mesmo RENTEV), sendo que a partir daí se considera que o controlo foi feito e a questão está encerrada. A isto acresce que o registo no RENTEV apenas visa conferir publicidade à DAV, não sendo sequer condição da sua eficácia (artigo 16.\%1 da Lei n. ${ }^{\circ}$ 25/2012).

\subsubsection{0 caso particular da vinculatividade da decisão do PCS}

Grande parte dos requisitos enunciados apenas são aplicáveis ao documento do testamento vital, não já à procuração concedida ao PCS, pelo menos na medida em que esta se limite a atribuir poderes genéricos de representação. Embora se mantenha a exigência de respeito pelos requisitos formais, por exemplo, quando à participação do notário (ou do funcionário do RENTEV) ou relativamente à capacidade do outorgante, já serão inaplicáveis muitos dos requisitos referentes ao conteúdo da procuração (por exemplo, a desadequação da vontade do outorgante face ao desenvolvimento do progresso científico), pelo menos quando o documento se limite a atribuir poderes de representação.

Coisa diferente sucederá caso a procuração estipule alguns limites à decisão que o PCS possa vir a tomar ou condicione de qualquer outra forma a decisão deste (sendo que a Lei n. ${ }^{\circ}$ 25/2012 não esclarece qual o efetivo conteúdo da procuração, pelo que é pensável que ambos os modelos sejam aceitáveis). De facto, quando a procuração estipule determinado conteúdo aos poderes representativos do PCS de novo assomam muitos dos requisitos 
legalmente exigidos na Lei n. ${ }^{\circ}$ 25/2012 em termos gerais para as DAV's, tais como a clareza do respetivo teor ou a sua não contrariedade face a normas legais, à ordem públicas e às boas práticas.

Um dos problemas suscitados pela procuração ao PCS consiste em saber como atuar quando estamos perante uma procuração que se limita a designar a pessoa do PCS e a atribuir-lhe poderes genéricos de representação em matérias atinentes à prestação de cuidados de saúde, mas o médico suspeitar que a decisão do PCS não corresponde àquela que seria tomada pelo próprio paciente (deixando já a ressalva que será difícil sustentar esta conclusão com um mínimo de fiabilidade, sobretudo face a pacientes com os quais o médico nunca teve qualquer contacto prévio). Se o médico estiver convicto da desadequação da decisão manifestada pelo PCS (sublinhe-se, não em termos objetivos mas do ponto de vista daquela que seria a decisão do paciente) não existe propriamente um fundamento na Lei n. ${ }^{\circ}$ 25/2012 que lhe permita atuar em contra da dita decisão, dado que a situação não se enquadra em nenhuma das supra referidas hipóteses. Por conseguinte, a única via aberta ao profissional de saúde parece ser a de recusar o cumprimento da decisão do PCS (dando conta do facto no processo clínico do paciente), atuar em conformidade com o que entenda ser a genuína decisão do paciente, arriscando-se às consequências legais que daí derivem caso venha a ser judicialmente acionado ${ }^{42}$. Ou então - de forma mais prudente, mas apenas possível caso haja margem de manobra temporal para tal - requerer uma apreciação judicial da decisão tomada pelo PCS, que a confirme ou, pelo contrário, permita ao médico desvincular-se da mesma e atuar de acordo com o que entenda ser o consentimento presumido do paciente.

42 Pelo próprio paciente, se porventura este não se rever na decisão do médico, mas sim naquela outra manifestada pelo PCS, ou pelos familiares do paciente caso este venha a falecer. Em relação a esta hipótese de recurso a meios judiciais, e como já por diversas vezes deixámos expresso (Vera Lúcia RAPOSO, "Directivas Antecipadas de Vontade...”, p. 199/201, "Entre a Vida e a Morte...”, p. 116, 117 e Do Ato Médico..., p. 169), note-se que não é necessário que o paciente sofra um dano no seu corpo ou na sua saúde para existir aqui ilícito criminal e, porventura (embora neste caso a questão seja mais controvertida e a pretensão mais difícil de sustentar), mesmo um ilícito civil. De facto, o artigo $156 .^{\circ}$ do $\mathrm{CP}$ considera criminosa qualquer atuação contra a vontade do paciente, ainda que seja em seu benefício e, por outro lado, pode também entender-se que a mera violação da sua vontade constituiu um dano não patrimonial indemnizável, mesmo que salve a vida do paciente, embora esta segunda hipótese, defensável em teoria, seja difícil de concretizar na prática, nomeadamente porque segundo o artigo 496.\% do CC apenas são indemnizáveis aqueles danos não patrimoniais que mereçam a tutela do direito, pelo que estamos em crer que quando o médico salve a vida do paciente, mesmo sem consentimento deste, o juiz cível tenderá a não considerar merecedor de tutela jurídica o eventual dano não patrimonial referente à violação da autodeterminação do paciente. 


\subsubsection{A vinculatividade da DAV face a pacientes não moribundos}

A natureza vinculativa da DAV não é feita depender do facto de se tratar de um tratamento destinado a prolongar infrutiferamente o período de vida, isto é, este regime não está cominado exclusivamente para doentes que estejam prestes a morrer. Esta conclusão justifica-se pelo facto de tal ressalva não constar do artigo 2 . $^{\circ}$ da Lei n. ${ }^{\circ} 25 / 2012$, que apenas declara que este mecanismo se destina a expressar os "cuidados de saúde que deseja receber, ou não deseja receber, no caso de, por qualquer razão, se encontrar incapaz de expressar a sua vontade pessoal e autonomamente". Ou seja, permite-se que o paciente manifeste, por meio da DAV, a mesma vontade que manifestaria caso estivesse em condições de o fazer, sendo que no que respeita ao consentimento oral e prestado no momento do ato nada impede que o paciente não moribundo recuse qualquer tratamento, ainda que dessa recusa advenha a sua morte. Em suma, não se exige que se trate necessariamente de um tratamento fútil a um pacientes prestes a falecer.

É certo que o artigo 2.\%/2/b da Lei n. ${ }^{\circ}$ 25/2012 se refere ao chamado encarniçamento terapêutico, isto é, aos tais tratamentos fúteis que em nada melhorarão a vida do paciente, apenas a prolongarão, por vezes durante breves momentos somente, sendo a morte um desfecho certo (e mesmo doloroso) a curto prazo. Esta referência poderia levar a entender que apenas se têm em vista intervenções médicas dessa natureza, mas não já tudo aquilo que não seja objetivamente fútil, na medida em que possa efetivamente salvar a vida do paciente. Porém, esta alínea insere-se no âmbito de uma listagem exemplificativa, onde se elencam alguns exemplos de possíveis conteúdos de uma DAV. Para além do facto de esta lista nem sequer pretender ser exaustiva, note-se que a alínea que a antecede (artigo 2. \%/2/a da Lei n. ${ }^{\circ}$ 25/2012) refere a possibilidade de recusa de "tratamento de suporte artificial de funções vitais", sem colocar qualquer ressalva quanto ao contexto em que tal recusa opere. Logo, bem poderemos estar perante uma recusa de um paciente eventualmente recuperável mas que, porém, rejeitou de antemão a aplicação de qualquer medida de suporte vital.

\subsection{Consequências do incumprimento de uma DAV vinculativa}

Perante uma DAV que preenche todos os requisitos legalmente cominados para vincular a conduta do médico deve o seu conteúdo ser respeitado. Contudo, o certo é que a Lei n. ${ }^{\circ}$ 25/2012 não estipula qualquer sanção para o incumprimento da DAV, pelo que há que apelar ao regime geral do ordenamento jurídico.

Assim, se o paciente recusar certo ato médico e este acabar por ser praticado poderemos estar perante o preenchimento do ilícito tipo de intervenções 
médico-cirúrgicas arbitrárias, previsto no artigo $156 .^{\circ}$ do $\mathrm{CP}$, que criminaliza as intervenções sem consentimento ${ }^{43}$.

Porém, pode igualmente suceder que o paciente solicite na sua DAV a aplicação de determinado ato médico, sendo que a violação se concretiza no facto de o médico não o ter levado a cabo. A análise deste segundo cenário deve começar por sublinhar um ponto importante: se o pedido do paciente implicar a prática de atos médico desconformes às leges artis, porque se revelam totalmente desajustados para o seu estado clínico e em nada o irão beneficiar, mas apenas prolongar o seu período de vida durante um brevíssimo período de tempo, o médico não estará vinculado a respeitar a DAV. É a própria Lei n. ${ }^{\circ}$ 25/2012 que retira força vinculativa às DAV's contrárias às boas práticas médicas (artigo 5.\%a), sendo exatamente o que se passa neste caso, dado que o respeito pela vontade do paciente poderá fazer o médico incorrer em distanásia, ou seja, tratamentos inúteis repudiados no artigo 59. $/ 3$ do $\mathrm{CDOM}^{44}$.

\subsection{A DAV e processo clínico}

O registo no processo clínico tem vindo a assumir uma importância crescente na prática clínica, ainda que continue a ser considerado pela classe médica uma tarefa menor. Porém, começa a crescer a consciência de que o registo no processo clínico assume uma importância vital para aperfeiçoar a prestação de cuidados de saúde, evitar a falta médica e salvaguardar a vida e a saúde do paciente. Além do mais, revela-se um importantíssimo instrumente em sede de litígio judicial, para avivar a memória dos intervenientes e fazer prova de certos factos, para além de que a ausência de registo pode implicar pesadas consequências processuais no âmbito do processo civil ${ }^{45}$.

O regime legal das DAV's veio reforçar ainda mais a importância do registo no processo clínico, pois que impõe que quer a decisão tomada com base no

43 Note-se que este não é o único tipo de crime que aqui está em causa. Para além de todos os outros tipos legais ligados à prática médica e à falta médica, cumpre ainda sublinhar que o conteúdo da DAV está sujeito ao regime de confidencialidade, cujo incumprimento dará lugar às respetivas sanções civis e criminais, nomeadamente, no que a estas últimas respeita, ao preenchimento dos tipos legais de crime previstos na LPDP, ao crime de violação de segredo profissional (artigo $195 .{ }^{\circ} \mathrm{CP}$ ) e ao crime de aproveitamento indevido de segredo (artigo 196. ${ }^{\circ}$ do CP).

44 Vera Lúcia RAPOSO, “Directivas Antecipadas de Vontade...”, p. 191,192, “Entre a Vida e a Morte...", p. 122 ss.

45 Sobre a importância do registo no processo clinico, André Dias PEREIRA, "Dever de Documentação...", p. 9/24. Da autora, "O Fim da "Letra de Médico...", em processo de publicação na revista Lex Medicinae, especialmente sobre as particularidades do processo clínico eletrónico. 
conteúdo da DAV, quer, ao invés, a decisão tomada contra a mesma, seja registada no processo clínico no paciente ${ }^{46}$ (artigos 6.\%/5 e 17.\%/2 da Lei n. ${ }^{\circ}$ 25/2012).

\section{Apreciação geral do regime jurídico da Lei $n .{ }^{\circ}$ 25/2012}

Por veze criticada por ser uma opção de meio-termo entre o respeito pelas DAV's e a sua recusa em prol do tratamento sistemático do paciente, certo é que o regime plasmado na Lei n. ${ }^{\circ}$ 25/2012 manifesta porventura a solução possível face a uma questão longe de ser consensual. Mais criticável seria que o legislador impusesse o respeito absoluto por uma DAV, sem cuidar de saber a sua atualização face à vontade do paciente ou a clareza dos seus termos.

O peso de orientar uma sensata aplicação deste regime legal recai agora sobre a doutrina, na interpretação que venha a fazer das suas disposições, e na jurisprudência, relativamente à decisão dos casos que se apresentem em tribunal. O quadro legal permite uma aplicação prática que acautele os interesses em jogo, de modo que será aos práticos envolvidos na matéria juristas, juízes, notários, RENTEV, médicos, administrações hospitalares, advogados - que caberá pugnar pela sua boa aplicação.

No que em particular respeita à prática médica, as DAV's acabam por ter um duplo efeito, contraditório nas suas consequências. Por um lado, conferem ao médico alguma tranquilidade ética e moral, ao desonerá-lo de boa parte dos intrincados problemas éticos e morais, religiosos e deontológicos, com que até agora se defrontava, forçando-o a tomar decisões para as quais não foi devidamente preparado e que, em bom rigor, não fazem parte do seu métier. Decisões desta índole desconcentram o médico daquela que é verdadeiramente o núcleo duro da sua profissão, a prestação de cuidados de saúde. Se o médico se concentrar em tais decisões dispersa a sua atenção daquilo que é realmente importante na prática médica. Mas, e por outro lado, as DAV's criam uma panóplia de questões jurídicas, nomeadamente quanto à forma de as rececionar, respeitar e documentar, isto é, quanto à gestão de um paciente portador de uma DAV. Para tal aconselha-se que as instituições de saúde disponham de protocolos de atuação, no sentido de definir junto de todos os seus profissionais qual a forma de atuar quando um paciente é portador de um testamento vital e/ou incumbiu um PCS de tomar decisões por $\mathrm{si}^{47}$. Se assim não for, isto é, se a forma de "gerir" a existência de uma DAV, que é um documento intrinsecamente jurídico, for deixada ao médico, sozinho na sua prática, não se duvida que as DAV's suscitarão mais problemas do que aqueles que resolvem.

46 Para além disso, as referidas decisões devem ainda ser comunicadas ao PCS, quando exista, e ao RENTEV (artigo 6. ${ }^{\circ} / 3$ da Lei n. ${ }^{\circ}$ 25/2012).

47 Também neste sentido, SEAUS, "Guía de Recomendaciones...", p. 15 ss. 


\section{Referências bibliográficas}

ANDRADE, Manuel da Costa - "Art. 157.”, in Comentário Conimbricense do Código Penal, Parte

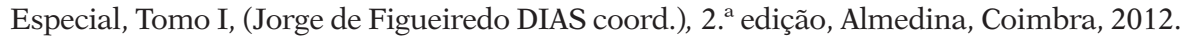

ANDRADE, Manuel da Costa - "Consentimento em Direito Penal Médico: O Consentimento Presumido", Revista Portuguesa de Ciência Criminal, 14, 2004

ANDRADE, Manuel da Costa - "Art. 156.", in Comentário Conimbricense do Código Penal, Parte Especial, Tomo I (Jorge de Figueiredo DIAS coord.), 2. ${ }^{a}$ edição, Almedina, Coimbra, 2012.

BRITO, Teresa Quintela de - "Interrupção de Alimentação e Hidratação Artificiais de Pessoa em Estado Vegetativo Permanente”, Revista Portuguesa de Ciência Criminal, 15, 2005.

BRITO, Teresa Quintela de - "Responsabilidade Penal dos Médicos: Análise dos Principais Tipos Incriminadores", Revista Portuguesa de Ciência Criminal, 12, 2002.

BRITO, Teresa Quintela de, et al. - "Crimes Contra a Vida: Questões Preliminares”, in Direito Penal - Parte Especial: Lições, Estudos e Casos (Teresa Quintela de BRITO coord.), Coimbra Editora, Coimbra, 2007.

COSTA, José de Faria - "O Valor do Silêncio do Legislador Penal e o Problema das Transplantações”, in Transplantações - Colóquio Interdiciplinar (25 de Março de 1993), Centro de Direito Biomédico da Faculdade de Direito da Universidade de Coimbra, n. 3, 1993.

ERS, Entidade Reguladora da Saúde - "Consentimento Informado (Relatório Final)”, Maio 2009, http://www.ers.pt/3590BDB6-5EFE-4B47-B05F-2B5CD0E1095E/FinalDownload/ DownloadId-1048468E9FF63ABE047053CBEBC23A30/3590BDB6-5EFE-4B47-B05F-2B5CD0E1095E/actividades/pareceres-e-recomendacoes/Estudo-CI.pdf (15/03/2010).

FAGNART, Jean-Luc - "Information du Patient et Responsabilité du Médecin”, in Actualités de Droit Médical (Eric THIRY coord.), Bruylant, Bruxelles, 2006.

FARIA, Paula Ribeiro de - “Aspectos Jurídico-Penais dos Transplantes”, Universidade Católica Portuguesa, Porto, 1995.

GALÁN CORTÉS, Julio César - "La Responsabilidad Médica y el Consentimiento Informado", at www.rmu.org.uy/revista/1999v1/art2.pdf (13/01/2010).

LOUREIRO, João Carlos - "Metáfora do Vegetal ou Metáfora do Pessoal?", Cadernos de Bioética, n. ${ }^{\circ}$ 8, 1994.

LOUREIRO, João Carlos - "Transplantações: Um Olhar Constitucional”, Argumentum 9, Coimbra Editora, Coimbra, 1995.

MAGELSSEN, Morten - "When Should Conscientious Objection be Accepted?", Journal of Medical Ethics, 38, 2012.

MELO, Helena Pereira de - "Directivas Antecipadas de Vontade", at www.fd.unl.pt/docentes_docs/ma/hpm_MA_7777 (02/09/2010).

PARZELLER, Markus, et al. - "Patient Information and Informed Consent before and After Medical Intervention”, Dtsch Arztebl, 104(9), 2007.

PEREIRA, André Dias - "Novos Desafios da Responsabilidade Médica: Uma Proposta para o Ministério Público”, https:/estudogeral.sib.uc.pt/jspui/bitstream/10316/2525/1/Novos\%20Desafios $\% 20$ da $\% 20$ Responsabilidade $\% 20 \mathrm{M} \% \mathrm{C} 3 \%$ A 9 dica-Revista $\% 20 \mathrm{do} \% 20 \mathrm{Minist} \% \mathrm{C} 3 \% \mathrm{~A} 9 \mathrm{rio} \% 20$ P\%C3\%BAblico\%20do\%20Paran\%C3\%A1\%20Andr\%C3\%A9\%20Pereira.pdf (19/01/2010).

PEREIRA, André Dias - "O Consentimento Informado na Relação Médico-Paciente", Coimbra, Coimbra Editora, 2004. 
PEREIRA, André Dias - "Dever de Documentação, Acesso ao Processo Clínico e sua Propriedade. Uma Perspectiva Europeia", Revista Portuguesa do Dano Corporal, ano XV, n. ${ }^{\circ} 16,2006$.

PEREIRA, André Dias - "Transplantation of Organs and Tissues and Some Reflections on the "Solidariaty" of the Human Cadaver in Portugal", European Journal of Health Law, 18, 2011.

RAPOSO, Vera Lúcia - "As Wrong Actions no Início da Vida (Wrongful Conception, Wrongful Birth e Wrongful Life) e a Responsabilidade Médica," Revista Portuguesa do Dano Corporal, 21, 2010.

RAPOSO, Vera Lúcia - "Directivas Antecipadas de Vontade: Em Busca da Lei Perdida", Revista do Ministério Público, Janeiro/Março, 2011.

RAPOSO, Vera Lúcia - "Self-Determination in the End of Life: A New Understanding of Human Dignity", in Third European Conference on Health Law - Book of Proceedings, 2011.

RAPOSO, Vera Lúcia - "Entre a Vida e a Morte: Responsabilidade Médica nas Decisões em Fim de Vida”, Lex Medicinae, ano 9 (18), 2012.

RAPOSO, Vera Lúcia - "Responsabilidade Médica em sede de Diagnóstico Pré-Natal (Wrongful Life e Wrongful Birth)”, Revista do Ministério Público, 132, Out/Dez 2012

RAPOSO, Vera Lúcia - "To Act or Not to Act, That Is the Question: Informed Consent in a Criminal Perspective", European Journal of Health Law, 19, 2012.

RAPOSO, Vera Lúcia - Do Ato Médico ao Problema Jurídico (Breves Notas sobre o Acolhimento da Responsabilidade Médica Civil e Profissional na Jurisprudência Nacional), Almedina, Coimbra, 2013.

RAPOSO, Vera Lúcia - "O Fim da "Letra de Médico": Problemas Suscitados pelo Processo Clínico Eletrónico em Sede de Responsabilidade Médica”, em processo de publicação na revista Lex Medicinae, 2013.

RAPOSO, Vera Lúcia - "O Direito à Imortalidade (O Exercício de Direitos Reprodutivos Mediante Técnicas de Reprodução Assistida e o Estatuto Jurídico do Embrião In Vitro)", Almedina, Coimbra, em processo de publicação.

REQUERO IBAÑEZ, Jose Luis - "El Testamento Vital y las Voluntades Anticipadas: Aproximación al Ordenamiento Español”, La Ley: Revista Jurídica Española de Doctrina, Jurisprudencia y Bibliografía, n. ${ }^{\circ}$ 4, 2002, págs. 1899-1904, at http://www. institutodebioetica.org/casosbioetic/formacioncontinuada/testamentovital/requero. pdf $(02 / 08 / 2013)$.

RODRÍGUEZ-ARIAS, David - "Una Muerte Razonable (Testamento Vital y Eutanasia)", Desclée de Brouwer, Bilbao, 2005.

SANDOR, Giulia - "Obbligo di Informazione Medica e Diritto Penale", L'Indice Penale, anno VII, n. ${ }^{\circ} 2,2004$.

SANZ CABALLERO, Susana - "El Comienzo y el Fin de la Vida Humana ante el TEDH: El Aborto y la Eutanasia a Debate", Cuadernos Europeos de Deusto, n. ${ }^{\circ} 31,2004$.

SEAUS (Sociedad Española de Atención al Usuario de Sanidad) - "Guía de Recomendaciones para el Ejercicio y Registro de las Voluntades Previas o Voluntades Anticipadas", Abril 2010.

VILLAS-BÔAS, Maria Elisa - "A Ortotanásia e o Direito Penal Brasileiro”, Revista Bioética, 16 (1), 2008. 
Resumo: No dia em que a morte chegar (decifrando o regime jurídico das diretivas antecipadas de vontade)

Hoje em dia o respeito pela vontade esclarecida do paciente é reconhecida como uma autónoma lex artis, cuja violação implica consequências deontológicas, civis e criminais. A grande novidade é que atualmente a lei admite expressamente que essa vontade surja sob a forma de testamento vital ou manifestada por um Procurador de Cuidados de Saúde, ambos modalidades legalmente autorizadas de diretivas antecipadas de vontade. Embora esta seja uma alteração muito ansiada e saudada, não se descuram os problemas que daí decorrem, desde o cuidado na elaboração do testamento vital e da procuração até ao processo da sua interpretação e efetivação.

Palavras-chave: Consentimento informado; responsabilidade médica; testamento vital; procurador de cuidados de saúde; processo clínico.

Abstract: $0 \mathrm{n}$ the day we die (deciphering the legal status of advance directives)

Nowadays, the respect for the enlightened consent of the patient is recognized as an autonomous lex artis, whose violation entails deontological, civil and criminal consequences. The great novelty is that currently the law explicitly allows that this consent may be expressed under the form of a living will or by a Health Care Proxy. Thought this is a very expected and saluted innovation, we must not neglect the problems arising from it, as the care needed in the redaction of the living will and the power of attorney and the process of their interpretation and execution.

Keywords: informed consent; medical liability; living will; health care proxy; clinical file.

\section{Pedido de separatas:}

VERA LÚCIA RAPOSO

vraposo@umac.mo; vera@fd.uc.pt 
